\title{
PENGARUH LATIHAN CIRCUIT BODYWEIGHT TERHADAP KEBUGARAN JASMANI, INDEKS MASSA TUBUH, PERSENTASE LEMAK TUBUH DAN FLEKSIBILITAS
}

\author{
Oleh: \\ Nanda Dwicahya dan Fatkurahman Arjuna \\ Jurusan Pendidkan Kesehatan dan Rekreasi FIK UNY
}

Abstrak

Memiliki status kebugaran jasmani yang baik dan tubuh yang ideal merupakan harapan semua orang. Sebagian besar member fitness Ros-In Hotel memliki tubuh yang kurang ideal dan kebugaran jasmani yang kurang bagus. Penelitian ini bertujuan untuk mengetahui seberapa besar pengaruh latihan circuit bodyweight terhadap kebugaran jasmani, indeks massa tubuh, persentase lemak tubuh, dan fleksibilitas member fitness Ros-In Hotel Yogyakarta.

Penelitian ini merupakan pre-experimental design dengan one-group pretestposttest design. Sampel dalam penelitian ini adalah member dengan usia antara 19-25 tahun, aktif minimal dua bulan, dan bersedia mengikuti latihan 18 kali pertemuan. Teknik pengambilan sampel menggunakan purposive sampling dengan jumlah sampel sebanyak 10 orang. Pengambilan data dilakukan dengan tes dan pengukuran. Instrumen yang digunakan yaitu tes rockport, stadiometer, timbangan, scinfold caliper, dan sit and reach. Analisis data penilitian menggunakan uji t untuk mengetahui apakah terdapat perbedaan variabel antara pretest dan posttest pada kelompok eksperimen.

Hasil penelitian ini menunjukan uji $\mathrm{t}$ data $\mathrm{VO}_{2} \mathrm{Max}$ diperoleh nilai $\mathrm{t}$ hitung $3.000>\mathrm{t}$ tabel 2.262, dan nilai p $0,015<0,05$ maka ada peningkatan $\mathrm{VO}_{2}$ Max yang signifikan. Hasil uji t IMT diperoleh nilai $\mathrm{t}$ hitung $6.957>\mathrm{t}$ tabel 2.262, dan nilai $\mathrm{p} 0,000<0,05$ maka ada penurunan berat badan yang sangat signifikan. Hasil uji t lemak tubuh

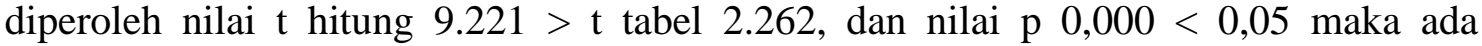
penurunan lemak tubuh yang sangat signifikan. Hasil uji t fleksibilitas diperoleh nilai $\mathrm{t}$ hitung $6.332>\mathrm{t}$ tabel 2.262, dan nilai p $0,000<0,05$ maka ada peningkatan fleksibilitas yang sangat signifikan.

Kata Kunci: bodyweight, kebugaran jasmani, indeks massa tubuh, lemak tubuh, fleksibilitas.

Manusia akan mengalami pergeseran pola hidup dari kerja dinamis menjadi kerja statis, misalnya untuk berjalan menuju ke tempat kerja dari semula berjalan kaki kemudian digantikan dengan menggunakan kendaran bermotor atau kendaraan lainnya. Pergeseran pola hidup apabila dilakukan berkepanjangan maka akan menjadi penyebab menurunnya tingkat kebugaran jasmani seseorang. Keadaan tubuh ketika kurang bergerak atau menurunnya tingkat kebugaran dapat menyebabkan berbagai masalah kesehatan. Munculnya berbagai macam penyakit merupakan dampak yang paling nyata dari pola hidup yang kurang

Pengaruh Latihan Circuit Bodyweight Terhadap Kebugaran Jasmani, Indeks Massa Tubuh, Persentase Lemak Tubuh Dan Fleksibilitas Oleh: Nanda Dwicahya dan Fatkurahman Arjuna 
bergerak. Penyakit yang sering muncul di antaranya diabetes melitus, hipertensi, jantung koroner, penyakit sendi, dan kegemukan (obesitas).

Harapan memiliki tubuh yang sehat, bugar, dan ideal tidak akan tercapai tanpa melakukan pola hidup sehat dengan berolahraga teratur, makan yang seimbang serta istirahat yang cukup. Berlatih menggunakan beban dalam (bodyweight) merupakan suatu program latihan yang diharapkan dapat meningkatkan minat masyarakat dan menjadi suatu daya tarik bagi masyarakat untuk berolahraga sehingga nantinya masyarakat memiliki tingkat kebugaran yang baik serta dapat mencegah timbulnya berbagai penyakit. Setiap orang yang melakukan olahraga akan mendapatkan dampak positif seperti tubuh yang proporsional, memiliki tulang yang kuat, persendian yang lentur, dan otot yang kuat. Tujuan member yang datang ke Fitness Center Lotus Nusantara Bersinar Ros-In Hotel sebagian besar untuk mengikuti latihan dengan program latihan kebugaran jasmani dan penurunan berat badan. Tujuan member memilih program tersebut untuk meningkatkan maupun memertahankan tingkat kebugaran, agar aktivitas sehari-harinya tetap bugar dan dapat bekerja secara produktif, serta menjaga berat badan tetap ideal.

Member mulai mengalami masalah ketika mengetahui Fitness Center Lotus Nusantara Bersinar Ros-In Hotel tidak menyediakan program latihan, seperti program latihan penurunan berat badan, program latihan penambahan berat badan, program latihan pembentukan otot, dan program latihan kebugaran jasmani, sehingga member yang ingin meningkatkan kebugaran jasmani atau menurunkan berat badan hanya terfokus menggunakan alat-alat seperti treadmill, crosstrainer, gym machine, dan sepeda statis. Melihat banyaknya member yang memiliki tujuan yang sama dan terbatasnya jumlah alat dan minimnya pengetahuan member tentang bentuk variasi latihan menimbulkan permasalahan baru bagi member maupun Fitness Center Lotus Nusantara Bersinar Ros-In Hotel.

Permasalahan itu timbul karena banyak member yang menginginkan jumlah alatnya di tambah agar mereka tidak terlalu lama pada saat menunggu menggunakan alat-alat yang ada di Fitness Center Lotus Nusantara Bersinar Ros-In Hotel, dengan demikian mereka berpikir latihan yang dilakukan tidak efektif dan waktu mereka menjadi tidak efisien hanya untuk menunggu menggunakakan alat. Selain pengetahuan yang kurang tentang bentuk variasi latihan member sering mengabaikan latihan perenggangan sebelum latihan maupun sesudah latihan. Sebagian member tidak mengetahui apa fungsi dan manfaat dari latihan perenggangan. Setiap pusat kebugaran seharusnya lebih teliti, tepat, dan professional dalam memberikan pengarahan kepada member baru maupu member lama, serta meningktkan 
pelayanan dari segi penyediaan program latihan, baik untuk program latihan kebugaran jasmani maupun program latihan lainnya.

Latihan beban dapat dilakukan dengan menggunakan beban dari berat badan sendiri (beban dalam) atau menggunakan beban luar yaitu beban bebas (free weight) seperti mesin beban (gym machine), barbell, dan dumbbell. Bentuk latihan yang menggunakan beban dalam (bodyweight) yang paling banyak digunakan seperti jumping jack, leg raises, plank jaks, push-up, sit-up, squat, lunge, mountain climber, high knee, ataupun back-up. Melihat permasalahan yang dialami member saat melakukan latihan untuk meningkatkan kebugaran jasmani dan menjaga tubuh karena keterbatasan alat dan kurangnya pengetahuan member tentang variasi latihan bodyweight, kondisi inilah yang kemudian mendorong peneliti untuk memperkenalkan program latihan circuit bodyweight kepada members Fitness Center Lotus Nusantara Bersinar Ros-In Hotel. Tempat latihan yang mendukung dan tidak memerlukan peralatan yang khusus latihan circuit bodyweight sangat memungkinkan untuk dilakukan, dengan begitu latihan circuit bodyweight dapat membatu mengatasi masalah member pada saat akan melakukan latihan.

\section{KAJIAN PUSTAKA}

\section{Latihan}

Menurut Suharjana (2013: 38) latihan adalah memberikan pembebanan fisik yang teratur, sistematis dan berkesinambungan sedemikian rupa sehingga dapat meningkatkan kemampuan dalam melakukan kerja dan meningkatkan kebugaran jasmani atau kemampuan fisik. Sedangkan Menurut Sukadiyanto (2011: 5) latihan berasal dari kata dalam bahasa Inggris yang dapat mengandung beberapa makna seperti: practice, exercise, dan training. Practice adalah aktivitas untuk meningkatkan keterampilan (kemahiran) berolahraga dengan menggunakan berbagai peralatan sesuai dengan tujuan dan kebutuhan cabang olahraganya. Exercise perangkat utama dalam proses latihan harian untuk meningkatkan kualitas fungsi sistem organ tubuh manusia, sehingga mempermudah olahragawan dalam penyempurnaan gerak. Training adalah penerapan dari suatu perencanaan untuk meningkatkan kemampuan berolahraga yang berisikan materi teori dan praktek, metode, dan aturan pelaksanaan sesuai dengan tujuan dan sasaran yang akan dicapai. Latihan kebugaran jasmani bertujuan untuk meningkatkan kualitas fungsional tubuh yang meliputi kualitas daya tahan paru jantung, kekuatan otot, daya tahan otot, kelentukan, dan komposisi tubuh, demikian pendapat (Faidillah, 2006: 10). 
Proses latihan akan mengakibatkan terjadinya superkompensasi. Menurut Djoko Pekik (2002: 43) superkompensasi adalah proses peningkatan pada kondisi awal yang secara bertahap mengarah ke tingkat yang lebih tinggi bila pembebanan yang diberikan tepat di atas ambang kepekaan disertai dengan pemulihan (recovery) yang cukup. Penyusunan dan perencanaan proses latihan seorang pelatih harus mempertimbangkan faktor-faktor yang disebut komponen-komponen latihan. Untuk meningkatkan kebugaran memerlukan latihan 35 kali per minggu, sisa hari yang lain dipergunakan untuk istirahat agar tubuh memiliki kesempatan melakukan recovery.

\section{Latihan Circuit Bodyweight}

Menurut Brett (2013: 8) latihan circuit bodyweight merupakan jenis latihan yang menggunakan berat badan sebagai beban. Circuit bodyweight merupakan penggabungan latihan aerobik dan latihan ketahanan yang dilakukan dalam waktu singkat dan dapat dilakukan dimana saja (Brett, 2013: 8). Sedangkan menurut Sadoso Sumosardjuno (2001: 157) latihan sirkuit dapat dilakukan dengan atau tanpa beban.

Latihan circuit body weight dilakukan secara sirkuit, yang terdiri atas beberapa macam gerakan yang disusun menjadi beberapa station atau pos, dengan pembebanan ringan sampai sedang, ulangan banyak, dilakukan beberapa sirkuit, di antara pos diberikan istirahat pendek, sedangkan di antara sirkuit diberikan istirahat yang sedikit lebih lama. Latihan dengan beban tubuh ini sangat menguntungkan dan efektif, karena dapat dilakukan dimana saja. Sejalan dengan hal ini, Burke (2001: 97) menjelaskan bahwa pada masa-masa sebelum mesin latihan ditemukan, semua latihan beban digunakan dengan menggunakan apa yang kita sebut dengan beban lepas dan beban tubuh.

Secara garis besar latihan dengan berat tubuh atau bodyweight ini termasuk dalam kategori latihan circuit. Study di Baylor University dan The Cooper Institute menunjukan bahwa pelatihan sirkuit adalah cara yang paling efisien waktu untuk meningkatkan kebugaran cardiovaskuler dan daya tahan otot, (Suharjana, 2013: 69). Selain meningkatkan kebugaran cardiovaskuler latihan sirkuit akan tercakup latihan untuk: (1) kekuatan otot, (2) ketahanan otot, (3) kelentukan, (4) kelincahan, (5) keseimbangan dan (6) ketahanan jantung paru, demikian pendapat Soekarman (1989) dalam (Suharjana, 2013: 70). 
Tabel 1. Petunjuk Takaran Circuit Weight Training

\begin{tabular}{|c|c|}
\hline Parameter Latihan & Pemula \\
\hline Lama program & $8-10$ minggu \\
\hline Beban & $30-40 \%$ \\
\hline Jumlah Pos & $8-12$ \\
\hline Jumlah Circuit & $2-3$ \\
\hline Volume & $25-25$ Menit \\
\hline Istirahat antar pos & 90 detik \\
\hline Istirahat antar circuit & $2-3$ menit \\
\hline Frekuensi per minggu & $2-3$ \\
\hline Irama & Cepat \\
\hline & Sumber: Suharjana, (2013: 71$)$
\end{tabular}

Menurut Corbin and Lindsey yang dikutip oleh Djoko Pekik (2009: 68) karakter circuit weight training antara lain: terdiri atas beberapa jenis latihan, seri, istirahat antar latihan sedikit, repetisi banyak, beban ringan, mengangkat beban berulang-ulang, latihan dimulai dari otot kecil ke otot besar, serta dilakukan bergantian antara anggota gerak atas dan bawah. Secara umum takaran latihan dengan metode ini dapat dilihat pada tabel 3.

Tabel 2. Takaran Circuit Weight Training

\begin{tabular}{|c|c|}
\hline Komponen & Takaran \\
\hline Beban (intensitas) & $40 \%-80 \%$ kemampuan \\
\hline Jumlah latihan atau pos & $6-12$ \\
\hline Repetisi per set & $10-25$ \\
\hline Sirkuit & $2-5$ \\
\hline Istirahat antar pos & Tanpa istirahat-30 dt \\
\hline Istirahat antar sirkuit & $>1$ meniit \\
\hline Lama latihan & $8-16$ minggu \\
\hline
\end{tabular}

Sumber: Djoko Pekik (2009: 69)

Sedangkan menurut Bompa (2015: 284) menyatakan secara umum takaran latihan dengan metode circuit dapat dilihat pada tabel 5.

Tabel 3. Training Parameters For Circuit Training

\begin{tabular}{|l|l|l|}
\hline Training parameter & Novice athlete & Experienced athele \\
\hline Duration of anatomical adaptation & 6-10 weeks & 2-4 weeks \\
\hline Load (if applicable) & $\begin{array}{l}\text { 20 reps down to 8 } \\
\text { throughout the entire } \\
\text { phase }\end{array}$ & $\begin{array}{l}\text { 12-15 reps down to 8 } \\
\text { throughout the entire } \\
\text { phase }\end{array}$ \\
\hline Buffer & $\begin{array}{l}1 \text { or 2 reps short of } \\
\text { exhaustion }\end{array}$ & $\begin{array}{l}1 \text { rep of exhaustion or to } \\
\text { exhaustion }\end{array}$ \\
\hline No of stasions per circuit & $10-15$ & $6-9$ \\
\hline No of circuit per session & 2 or 3 & 3 or 4 \\
\hline Total time of circuit training & $35-60$ minutes & $40-60$ minutes \\
\hline
\end{tabular}

Pengaruh Latihan Circuit Bodyweight Terhadap Kebugaran Jasmani,

Indeks Massa Tubuh, Persentase Lemak Tubuh Dan Fleksibilitas

Oleh: Nanda Dwicahya dan Fatkurahman Arjuna 


\begin{tabular}{|l|l|l|}
\hline session & & \\
\hline Rest interval between exercise & $30-90$ seconds & $30-120$ seconds \\
\hline Rest interval between circuit & $2-3$ minutes & $1-3$ minutes \\
\hline Frequency per week & 2 or 3 & 3 or 4 \\
\hline
\end{tabular}

Sumber: Bompa (2015: 284)

Melalui beberapa penjelasan di atas dapat ditarik kesimpulan bahwa metode latihan yang digunakan dalam penelitian ini adalah sistem circuit. latihan circuit bodyweight menggunakan sistem sirkuit. Adapun program latihan circuit bodyweight yang digunakan dalam penelitian ini dijelaskan pada tabel 6 .

Tabel 4. Program Latihan Circuit Bodyweight

\begin{tabular}{|l|l|l|}
\hline \multicolumn{1}{|c|}{ Jenis Latihan } & \multicolumn{1}{|c|}{ Takaran Latihan } & \multicolumn{1}{|c|}{ Keterangan } \\
\hline Latihan Circuit & Frekuensi $: 3$ kali/seminggu & Pos : 12 pos \\
Bodyweight & Repetisi : 20 & Metode : cirkuit \\
& Sirkuit : 3 & training \\
& $\begin{array}{l}\text { Recovery }: 30-40 \text { detik antar pos, } \\
120-160 \text { detik antar sirkuit }\end{array}$ & \\
\hline
\end{tabular}

\begin{tabular}{|c|c|}
\hline \multicolumn{2}{|c|}{ SESI 1 SAMPAI SESI 6} \\
\hline Fase Latihan & Latihan Circuit Bodyweight \\
\hline $\begin{array}{l}\text { Pemanasan Streaching Statis } \\
\text { Latihan Inti: } \\
\text { Circuit Bodyweight } \\
\text { Pendinginan Streaching Statis }\end{array}$ & $\begin{array}{ll}\text { Frekuensi }: & 3 \text { kali/minggu } \\
\text { Repetisi } \quad: 20 \\
\text { Sirkuit } \quad: 3 \\
\text { Pos } \quad: 12 \\
\text { Recovery }: 40 \text { detik antar pos, } 160 \\
\text { detik antar sirkuit }\end{array}$ \\
\hline
\end{tabular}

\begin{tabular}{|c|c|}
\hline \multicolumn{2}{|c|}{ SESI 7 SAMPAI SESI 12} \\
\hline Fase Latihan & Latihan Circuit Bodyweight \\
\hline $\begin{array}{l}\text { Pemanasan Streaching Statis } \\
\text { Latihan Inti: } \\
\text { Circuit Bodyweight } \\
\text { Pendinginan Streaching Statis }\end{array}$ & $\begin{array}{l}\text { Frekuensi : } 3 \text { kali/minggu } \\
\text { Repetisi }: 20 \\
\text { Sirkuit } \quad: 3 \\
\text { Pos } \quad: 12 \\
\text { Recovery }: 35 \text { detik antar pos, } 140 \\
\text { detik antar sirkuit }\end{array}$ \\
\hline
\end{tabular}




\begin{tabular}{|c|c|}
\hline \multicolumn{2}{|c|}{ SESI 13 SAMPAI SESI 18} \\
\hline Fase Latihan & Latihan Circuit Bodyweight \\
\hline $\begin{array}{l}\text { Pemanasan Streaching Statis } \\
\text { Latihan Inti: } \\
\text { Circuit Bodyweight } \\
\text { Pendinginan Streaching Statis }\end{array}$ & $\begin{array}{l}\text { Frekuensi : } 4 \text { kali/minggu } \\
\text { Repetisi } \quad: 20 \\
\text { Sirkuit } \quad: 3 \\
\text { Pos } \quad: 12 \\
\text { Recovery }: 30 \text { detik antar pos, } 120 \\
\text { detik antar sirkuit }\end{array}$ \\
\hline
\end{tabular}

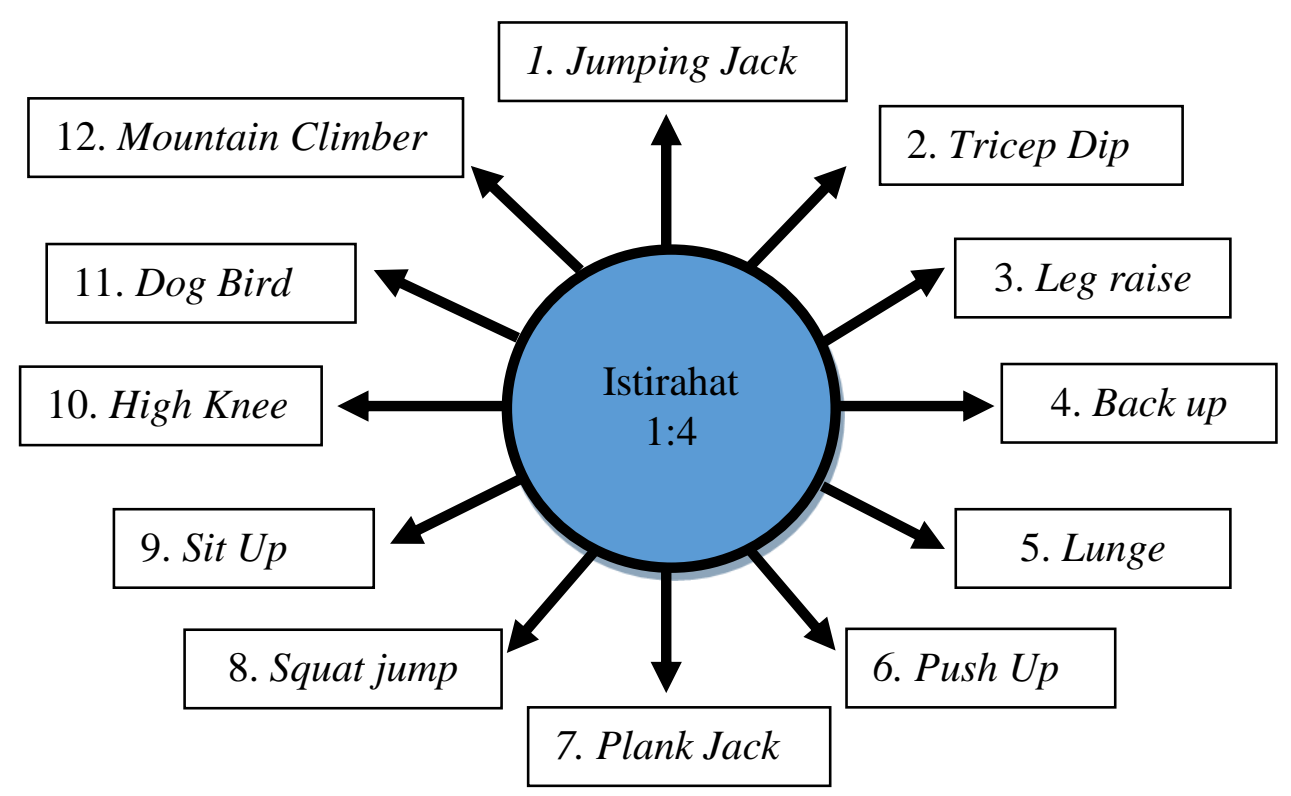

Gambar 1. Alur Latihan Circuit Bodyweight

Latihan circuit bodyweight dilakuakan selama 18 kali pertemuan, dengan frekuensi 3 kali/minggu. Pertemuan ke-1 sampai dengan pertemuan ke-6 menggunakan 12 pos, repetisi 20, 3 sirkuit, recovery 1:4 (istirahat antar pos 40 detik dan istirahat antar sirkuit 160 detik), cara melakukannya member terlebih dahulu melakukan pemanasan dan perenggangan, kemudian memulai latihan circuit bodyweight dari pos 1, setalah menyelesaikan pos 1 member istirahat 40 detik kemudian melanjutkan ke pos 2 dan istirhat lagi 40 detik, lakukan sampai pos 12, apabila member melakukan latihan dari pos 1 sampai pos 12 maka member telah menyelesaikan 1 sirkuit. Setelah menyelesaikan 1 sirkuit member istirahat selama 160 detik, selanjutnya ulangi latihan bodyweight sampai menyelesaikan 3 sirkuit. Pada pertemuan ke-7 sampai dengan pertemuan ke-12 masih tetap menggunakan 12 pos, repetisi 20, 3 sirkuit, tetapi waktu istirahat di per cepat (istirahat antar pos 35 detik dan istirahat antar sikuit 140 detik). 
Sedangkan pada pertemuan ke-13 sampai dengan pertemuan ke-18 menggunakan 12 pos, repetisi 20, 3 sirkuit, dan waktu istirahat antar pos 30 detik, antar sirkuit 120 detik.

Setiap gerakan latihan bodyweight memiliki sasaran perkenaan otot. Perkenaan otot yang dilatih dibagi menjadi menjadi extremitas atas, tutbuh bagian tengah, dan extremitas bawah. Total latihan bodyweight ada 12 gerakan yang terdiri dari 3 gerakan untuk melatih extremitas atas, 4 gerakan untuk melatih tubuh bagian tengah, dan 5 gerakan untuk melatih extremitas bawah. Pembagian gerakan tidak di samaratakan karena gerakan diperbanyak pada penggunaan kaki agar gerakan dapat meningkatkan kebugaran jasmani.

\section{METODE PENELITIAN}

Desain penelitian dalam penelitian ini adalah pre-experimental design menggunakan one-group pretest-posttest design. Populasi dalam penelitian ini adalah member Fitness Center Lotus Nusantara Bersinar Ros-In Hotel. Sampel adalah bagian dari jumlah dan karakteristik yang dimiliki oleh populasi tersebut. Teknik sampling menggunakan sampling purposive, yaitu teknik penentuan sampling dengan pertimbangan tertentu (Sugiyono, 2015: 81-85). Pertimbangan tersebut antara lain: (1) member Fitness Center Lotus Nusantara Bersinar yang aktif latihan selama minimal dua bulan, (2) member putri usia 19-25 tahun, dan (3) bersedia mengikuti latihan selama 18 kali pertemuan.

\section{HASIL PENELITIAN}

Subjek dalan penelitian ini adalah member Fitness Center Lotus Nusantara Bersinar Ros-In Hotel Yogyakarta yang berjumlah 10 orang, terdiri dari 10 perempuan. Penelitian ini dilaksanakan dengan di awali pengambilan data pretest pada tanggal 11 Desember 2016, dan diakhiri dengan pengambilan data posttest pada tanggal 22 Januari 2017. Data dalam penelitian ini terdiri atas status kebugaran jasmani (VO2Max), indeks massa tubuh, persentase lemak tubuh, dan fleksibilitas.

A. Kebugaran Jasmani (VO2Max)

Hasil pretest nilai minimal $=30$, nilai maksimal $=52$, rata-rata $=37,30$, dan simpang baku $=8,14$. Sedanglan Pada hasil posttest nilai minimal $=30$, nilai maksimal $=53$, ratarata $=37,80$, dan simpang baku $=8,23$. Terjadi peningkatan VO2Max pada hasil posttest, meskipun masih dalam status yang sama, tetapi peningkatan itu terlihat pada waktu tempuh yang semakin singkat atau hasil peningkatan dapat dilihat dari selesih rerata antara pretest dan posttest yaitu sebesar 0,5.

B. Indeks Massa Tubuh (IMT) 
Hasil pretets nilai minimal $=19,48$, nilai maksimal $=32,93$, rata-rata $=23,40$, dan simpangan baku $=5,12$. Sedangkan hasil posttest nilai minimal $=18,91$, nilai maksimal $=$ 31,74 , rata-rata $=22,77$, dan simpangan baku $=4,61$. Hasil perhitungan indeks massa tubuh terjadi perubahan, perubahan tersebut pada berat badan yang mengalami penurunan pada seluruh member, yang dapat dilihat dari selisih rerata antara pretest dan posttest yaitu sebesar 0,63 .

C. Lemak tubuh

Hasil pretets nilai minimal $=40$, nilai maksimal $=86$, rata-rata $=56,30$, dan simpangan baku $=15,1$. Sedangkan hasil posttest nilai minimal $=35$, nilai maksimal $=80$, rata-rata $=51,70$, dan simpangan baku $=14,1$. Hasil penelitian lemak tubuh, lemak mengalami penurunan pada seluruh member, yang dapat dilihat dari selisih rerata antara pretest dan posttest yaitu sebesar 4,6.

D. Fleksibilitas

Hasil pretets nilai minimal $=20$, nilai maksimal $=35$, rata-rata $=27,80$, dan simpangan baku $=4,42$. Sedangkan hasil posttest nilai minimal $=23$, nilai maksimal $=36$, rata-rata $=29,20$, dan simpangan baku $=4,14$. Pada hasil penelitian fleksibilitas terjadi perubahan yaitu perubahan pada kelentukan yang mengalami peningkatan pada seluruh member, yang dapat dilihat dari selisih rerata antara pretest dan posttest yaitu sebesar 1,4.

\section{PEMBAHASAN}

Penelitian ini bertujuan untuk mengetahui pengaruh latihan circuit bodyweight terhadap kebugaran jasmani, indeks massa tubuh, persentase lemak dan fleksibilitas member Fitness Center Lotus Nusantara Bersinar Ros-In Hotel Yogyakarta. Penelitian ini dilakukan dengan memberikan perlakuan latihan circuit bodyweight pada member. Pengukuran data dilakukan sebanyak dua kali yaitu sebelum dan sesudah perlakuan untuk mengetahui seberapa besar pengaruh dari penerapan model latihan circuit bodyweight. Circuit bodyweight terbukti berpengaruh signifikan terhadap peningkatan VO2Max. Hal tersebut menunjukkan adanya peningkatan waktu yang signifikan VO2Max sebelum dan sesudah diberi perlakuaan circuit bodyweight. Hal itu terjadi karena suatu pelatihan yang dilakukan berualng-ulang dan terprogram selama enam minggu akan terpola pada sistem daya tahan kardiovaskuler yang menghasilkan efek adaptasi sehingga memberikan pengaruh terhadap peningkatan VO2Max.

Hasil tersebut dapat dijelaskan Fox dalam Suharjana (2013: 61-62), berpendapat bahwa untuk mengembangkan daya tahan aerobik dapat digunakan beberapa metode antara lain 
dengan metode circuit training, bentuk latihannya yang terdiri dari beberapa pos latihan yang dilakukan secara berurutan dari pos satu sampai pos terakhir. Jumlah pos antara 8-12. Istirahat dilakukan pada jeda antar pos satu dengan pos yang lainnya.

Hasil analisis diketahui circuit bodyweight terbukti berpengaruh signifikan terhadap penurunan berat badan. Hal itu terjadi karena berlatih secara circuit atau kontinyu membuat lemak dalam tubuh akan cepat terbakar. Selain itu latihan circuit dikatakan latihan aerobik, yang merupakan latihan efektif dalam mebakar lemak, dengan menurunnya lemak tubuh maka secara tidak langsung berat badan juga akan menurun. Ditambah lagi dengan pengaturan pola makan secara sehat dan benar kemudian dilanjutkan dengan mengatur pola istirahat dengan baik, maka akan lebih mudah tercapai tujuan dari latihan yaitu penurunan berat badan. Hasil tersebut dapat dijelaskan bahwa penurunan berat badan pada member fitness center setelah mengikuti program circuit bodyweight. Sesuai Brett (2013: 9) latihan circuit bodyweiht yang menggunakan beberapa otot-otot besar dengan sedikit waktu istirahat antar pos dapat menjadi cara yang cepat dan efisien untuk menurunkan berat badan belebih dan lemak tubuh.

Circuit bodyweight juga terbukti berpengaruh signifikan terhadap penurunan persentase lemak tubuh member fitnessHal tersebut dapat terjadi karena dengan latihan yang sifatnya kontinyu dan berlangsung lama tubuh akan banyak memerlukan energi untuk melakukan aktivitas. Energi yang diperoleh tubuh salah satunya berasal dari pembakaran lemak. Sehinga latihan circuit bodyweight memberikan efek pada pembakaran lemak tubuh. Sesuai dengan Djoko Pekik (2004 : 81) menyatakan bahwa melakukan latihan fisik, tubuh dapat memelihara kestabilan jumlah lemak dan berat badan sehingga tubuh akan ideal.

Hasil analisis juga diketahui latihan circuit bodyweight terbukti berpengaruh signifikan terhadap fleksibilitas. Berdasarkan hasil analisis diketahui nilai rata-rata data pretest fleksibilitas sebesar 27,80 dan pada saat posttest nilai rata-rata fleksibilitas mengalami peningkatan yang signifikan menjadi 29,20. Hal itu terjadi karena sebelum diberi perlakuan circuit bodyweight member tidak memahami manfaat perenggangan sebelum latihan dan sesudah latihan. Setelah melakukan perenggangan secara rutin dan latihan circuit bodyweight ruang gerak sendi menjadi lebih leluasa dan otot yang seebelumnya kaku menjadi lebih elastis. Seperti pendapat Soekarman (1989) dalam (Suharjana, 2013: 70) latihan sirkuit akan tercakup latihan untuk: (1) kekuatan otot, (2) ketahanan otot, (3) kelentukan, (4) kelincahan, (5) keseimbangan dan (6) ketahanan jantung paru. 


\section{KESIMPULAN}

Berdasarkan uraian di atas di ketahui latihan circuit bodyweight dapat memberikan pengaruh yang signifikan terhadap kebugaran jasamani, indeks massa tubuh, persentase lemak tubuh dan fleksibilitas. Hal tersebut dapat dijelaskan bahwa pemilihan program latihan yang tepat dengan dosis latihan yang sesuai akan memberikan dampak yang efektif terhadap hasil yang ingin dicapai. Seperti pendapat Suharjana (2013: 129) menyebutkan bahwa bentuk latihan yang sesuai dengan prinsip-prinsip latihan serta takaran yang ada diharapkan dapat memberikan hasil yang maksimal, sehingga tujuan dari program tersebut tercapai. 


\section{DAFTAR PUSTAKA}

Bambang Priyonoadi \& Endang Rini Sukanti. (2001). Pengaruh Latihan Beban dan Latihan Senam Aerobik terhadap Penurunan Persentase Lemak Tubuh dan Peningkatan Kesegaran Kardio Respirasi. Majalah Ilmiah Olahraga. Hlm 97-108.

Brett Klika \& Chris Jordan. (2013). High Intensity Circuit Training Using Bodyweight. ACSM's Health \& Fitness Journal. Volume 17. No. 3. Hal. 8-13.

Bompa, T.O. \& Buzzichelli, C. (2015). Periodization Training for Sport. United States: Human Kinetics.

Burke, Edmund R. (2001). Panduan Lengkap Latihan Kebugaran di Rumah. (Alih Bahasa: Eri Desmani Nasution). Jakarta: PT Raja Grafindo Persada.

Danardono. (2006). Perencanaan Program Latihan. Materi. Pelatihan Instruktur Fitness Tingkat Dasar Angkatan VII. Yogyakarta: FIK UNY.

Faidillah K. (2006). Dasar- Dasar Latihan Kebugaran. Yogyakarta: Fitness Center FIK UNY Klinik Kebugaran.

I Dewa Nyoman Supariasa, dkk. (2002). Penilaian Status Gizi. Jakarta: EGC

Muhammad Ikhwan Zein. (2000). Exercise and Physical Fitness. Diakses dari https://www.google.co.id/url? sa=t\&rct=j\&q=\&esrc=s\&source=web\&cd=2\&cad=rja\& uact $=8 \&$ ved $=0$ ahUKEwieoabo $\quad$ HNAhWHuY8KHS0cDwYQFggfMAE\&url=http $\%$ 3A\%2F\%2Fkuliah.fkuii.org\%2Findex.php\%3Foption\%3Dcom_phocadownload\%26v iew\%3Dcategory\%26download\%3D855\%3Aexercise\%2520and\%2520physical\%252 0fitness\%26id\%3D76\%3Aelektif-410\%26Itemid\%3D10738\&usg=AFQjCNHWZRSTQ77nPC5ZbpvdMomMHki4EA\& sig2=DsaK2oQo5Wh7vciGRQhMBg\&bvm=bv.126993452,d.c2I. pada tanggal 15 Oktober 2016, jam 17.04 WIB.

Nancy Clarck. (2001). Petunjuk Gizi untuk Setiap Cabang Olahraga. Jakarta: PT. RajaGafindoPersada.

Presto Tri Sambodo. (2014). Pengaruh Latihan Circuit Body Weight Terhadap Kebugaran Jasmani dan Komposisi Tubuh pada Member Fitnes Center GOR UNY. Skripsi. Yogyakarta: FIK UNY.

Rusli Lutan. (2002). Menuju Sehat dan Bugar. Jakarta. Direktorat Jendral Olahraga dan Depdiknas.

Sadoso Sumosardjuno. (2001). Panduan Lengkap Bugar Total. Jakarta: PT. RajaGrafindo Persada.

Sharkey, J. Brian. (2003). Kebugaran dan Kesehatan. Jakarta: PT. RajaGrafindo Persada.

Suharjana. (2013). Kebugaran Jasmani. Yogyakarta : Jogja Global Media Syarif Hidayat. (2014). Pelatihan Olahraga; Teori dan Metodologi. Yogyakarta: Graha Ilmu. 